\title{
correspondence
}

\section{INFCE looks for technical and institutional solutions}

SIR,--I would like to make some corrections to the report entitled "INFCE halfway through" (8 March, page 112). Although the idea of INFCE was first suggested at the London Summit, it was set up in Washington in October 1977 and involves not only the Western industrialised nations but the Soviet Union, several of the East European States and quite a number of developing countries. It is incidentally organised into eight working groups, not twelve.

At the time INFCE started, the proliferation risks of reprocessing were indeed judged differently by on the one hand the United States and Canada and on the other all the major nuclear power users (not simply the UK as your article suggests). These countries all felt that the case for reprocessing must take into account environmental and economic factors; and that as spent fuel contained plutonium, spent fuel storage also carried proliferation risks. However, as a result of studies in INFCE it is now apparent that some intermediate fuel storage is necessary because it is most unlikely that world reprocessing capacity will be sufficient to deal with all spent fuel arising for perhaps another 20 years, and some spent fuel will therefore have to be stored for a considerable time.

Your article is correct in implying that there is no simple technical fix to the proliferation risks arising from the growing spread of civil nuclear power. But we are also engaged in an examination of institutional measures to counter the dangers of proliferation.

The International Atomic Energy Agency has already shown itself to be an eminently valuable institution, especially its safeguards system, and it may well be that internationally controlled plutonium storage and internationally controlled spent fuel storage can be important further additions to world confidence.

Yours faithfully,

Sir Hermann Bond

Chief Scientist,

Department of Energy, London.

\section{Defence R\&D and SRC budgets are not comparable}

SiR.-I was interested to see your editorial (1 March, page 1). Most members of the scientific community in the UK will agree with you that the "difficult question"- the minimum rate at which expenditure by the research councils should grow so as to sustain the health of research in the country-should be addressed with urgency. It is good to see a lead from the ABRC, for it is not only sustenance that is at stake; there is a vital need to repair the attritions of the past decade or more.
I regret, however, that you should have confused this important problem with a less than adequate examination of the relativities of government $R \& D$ resource allocation. The defence R\&D budget and SRC expenditure set out to do quite different things: SRC remains, I believe, dedicated to the promotion of research of 'timeliness and promise' and the research councils accept responsibility - as they must-for the nurturing of the research function in universities, polytechnics and their own laboratories. Less than $1 \%$ of defence R\&D expenditure can be identified with the support of innovative research: a matter of considerable concern to myself and my colleagues here. As the 1979 Defence White Paper-- or the more recent Review of Cmnd 5046 -indicates, more than $70 \%$ is invested in British industry (including, for instance, the important area of electronics) and is dedicated to the short term task of developing new equipment essential to the Armed Forces and national defence. Thus about $25 \%$ of the R\&D budget finds its way to the defence

establishments, and this too is overwhelmingly dedicated to short and medium term development work.

Moreover, I fear that your misunderstanding of the equivalence (or lack of it) between defence R\&D and the SRC budgets reads over to your remarks on the competence of personnel in our R\&D establishments. It will be clear from the above that the criteria for judging the ability and performance of scientists and engineers in defence laboratories must, in general, be quite different from those applied to my colleagues in the universities. This is not to say, of course, that MOD scientists inhabit a world isolated from the wider scientific community. We are always looking for ways of promoting contact; but communication is already frequent and fruitful, much of it through the Defence Scientific Advisory Council, which monitors very carefully the programmes of all R\&D laboratories and which submits independent annual reports to the Secretary of State. There exist other forms of "peer review", internal and external, both for programmes and for individual scientists and engineers.

There may, in fact, be less complacency in defence about the need to repair the innovative function than there is elsewhere. The R\&D establishments have suffered considerable erosion for a number of years, during which their work has been directed away from the long term innovative task. It would be unfair to attack them now on the basis of a spurious comparison of their contribution to microbiology or solid state physics, or whatever, with those emerging from research sponsored by the research councils. The latter are conducted for different purposes, and are different in kind.

$$
\text { Yours faithfully, }
$$
Ronald Mason

Chief Scientific Adviser,

Ministry of Defence, London.

\section{Piltdown stains}

SIR,-In your correspondence columns (22 February, page 596) Dr L. B. Halstead recalls that he refuted my suggestion (The Times, 7 November 1978) that Sollas may have used potassium bichromate to harden fossils to which he applied his serial sectioning technique. I wrote a letter in reply, but it was not published owing to the temporary cessation of The Times. I accept the validity of the evidence which Halstead found in the records of the University Museum, Oxford, showing that all the fossils to which Sollas applied serial sectioning were hard by nature, and therefore required no artificial hardening. The truth of the matter is that after the passage of some 70 years there is nothing to be gained by speculating on the purpose for which Sollas ordered the packet of bichromate crystals. As I pointed out in my letter to The Times of 7 November, Charles Dawson himself stated that he soaked some of the Piltdown bones in a solution of potassium bichromate, allegedly for the purpose of hardening them. Only by special pleading could anyone argue that this chemical was ordered by Sollas for delivery to him in Oxford, after which (one would have to suppose) it was forwarded to Dawson in Lewes with instructions as to how it might be used. These are the thoughts of a Jabberwocky! Dawson would have had no difficulty in obtaining potassium bichromate from a pharmacy in Sussex.

Researches by Dr (now Sir Frank) Claringbull and $\operatorname{Dr}$ M. H. Hey at the British Museum (Natural History) (Further Contributions to the Solution of the Piltdown Problem, Bulletin of the British Museum (Nat. Hist.), Geology series, vol 2, no 6 (1955)) showed that the Piltdown cranial bones had been artificially stained by treatment with a solution of an iron sulphate. The additional use of a bichromate solution can now be understood because it would serve to aid the oxidation of a ferrous iron salt and thus the production of rusty staining. So the bones, which were originally of pale biscuit colour, in the end matched the dark reddish-brown Piltdown gravel in which they were supposed to have been found

Dawson is known to have carried out experiments on the staining of bones and flints. He may well have required advice from somebody with greater knowledge of chemistry than he himself possessed, but it is unlikely that he would have sought help from the Oxford Professor of Geology. He was in a position to obtain chemical advice locally: in his first paper on Piltdown, read to the Geological Society in December 1912, Dawson thanks Mr S. A. Woodhead, Public Analyst of East Sussex, for chemically testing a piece of the Piltdown cranium and reporting that no organic matter could be detected in it (recent analyses of the cranial bones showed protein residues represented by $0.2-1.9 \%$ nitrogen)

$$
\text { Yours faithfully, }
$$

Oxford, UK

\section{Kenneth P. OAKley}

